\title{
The Effect of The Use of Multimedia Flip Book With the Flipped Classroom Approach in Vocational School
}

\author{
Rahmi Oktarina \\ Fakultas Teknik, Universitas Negeri Padang, Padang, Indonesia \\ e-mail: rahmyoktarina2016@gmail.com
}

Ambiyar

Fakultas Teknik, Universitas Negeri Padang, Padang, Indonesia e-mail:mbiyar@ft.unp.ac.id

M.Giatman

Fakultas Teknik, Universitas Negeri Padang, Padang, Indonesia e-mail: giatman@ft.unp.ac.id

Fadhilah

Fakultas Teknik, Universitas Negeri Padang, Padang, Indonesia e-mail: Fadhilah@ft.unp.ac.id

Mukhlidi Muskhir

Fakultas Teknik, Universitas Negeri Padang, Padang, Indonesia e-mail: muskhir@ft.unp.ac.id

Hansi Effendi

Fakultas Teknik, Universitas Negeri Padang, Padang, Indonesia e-mail:hans_79@ft.unp.ac.id

\section{A R T I C L E I N F O}

\section{Article history:}

25 December 2020

Received in revised form

01 January 2021

Accepted 25 January 2021

Available online 03 February 2021

\section{Kata Kunci: \\ Multimedia, Flip Book}

Flipped Classroom

Keywords:

Multimedia, Flip Book,

Flipped Classroom

\begin{abstract}
A B S T R A K
Masalah yang dihadapi dalam pembelajaran adalah kurangnya kreativitas kemampuan berpikir siswa sehingga mengalami kendala dalam proses praktikum. Tujuan penelitian ini adalah untuk menganalisis keefektifan multimedia Flip Book dengan pendekatan flipped classroom di SMK. Penelitian ini menggunakan quasi-experimental/quasiexperimental design dengan pretest-posttest Control Group Design. Teknik pengumpulan data dengan observasi, wawancara, dan tes. Instrumen yang digunakan untuk mengumpulkan data adalah kuesioner. Pre-test dilakukan di awal untuk melihat kemampuan awal siswa sebelum diberikan perlakuan, Post-test dilakukan untuk menguji keefektifan atau pengaruh penerapan perlakuan. Dalam penelitian ini teknik analisis data menggunakan 3 uji statistik, yaitu (1) uji normalitas, (2) uji homogenitas dan (3) uji hipotesis. Melalui penggunaan pengujian hipotesis menunjukkan hasil HO ditolak dan $\mathrm{HI}$ diterima dengan taraf signifikansi 5\% sehingga diperoleh nilai $(P<0,05)$. Kesimpulannya, penggunaan Multimedia Flip book dengan pendekatan Flipped Classroom dapat meningkatkan kemampuan berpikir mahasiswa jurusan teknik jaringan komputer pada mata kuliah sistem operasi. Sehingga nantinya pada penelitian selanjutnya dapat diterapkan pada mata pelajaran lain untuk membantu proses pembelajaran dan meningkatkan kreativitas siswa SMK.
\end{abstract}

\begin{abstract}
A B S T R A C T
The problem encountered in learning operating system teaching materials majoring in network computer engineering is the lack of creativity in students' thinking skills so that they experience obstacles in the practical process. This study used a quasi-experimental design with a pretest-posttest Control Group Design. Data collection techniques using tests. The pre-test was carried out at the beginning to see the students' initial abilities before being given treatment, the post-test was carried out to test the effectiveness or compliance of the application of the treatment. In this study, the data analysis technique used 3 statistical tests, (1) normality test, (2) homogeneity test and (3) hypothesis testing. Through the use of hypothesis testing to show the results of $\mathrm{H} 0$ is rejected and $\mathrm{H} 1$ is accepted with a significance level of $5 \%$ so that the value is $(\mathrm{P}<0.05)$. The conclusion is that the use of the Flip book Multimedia with the Flipped Classroom approach is able to improve the thinking skills of students majoring in network computer engineering in the operating system subject. So that later research can be applied to other subjects to help the learning process and increase the creativity of vocational high school students.
\end{abstract}




\section{Introduction}

The world of education today requires technology to support the development of science. Along with the development of technology, the teaching and learning process does not only rely on face-to-face meetings held in the classroom, but also relies on other media, such as ICT media that can be used as a form of disseminating learning materials. (Wulandari, Sudatha, \& Simamora, 2020; Yusri, 2016). Learning activities are a major part of the education sector in schools. Efforts to increase student interest in the learning process require updates regarding the media used (Qumillaila, Susanti, \& Zulfiani, 2017; Sunismi, 2015). The use of learning media or technology in the classroom will improve learning and facilitate learning (Lovy Herayanti, Habibi, \& Fuaddunazmi, 2017; Puspitorini, Subali, \& Jumadi, 2014). Educators have expanded the list of media used by integrating new technological developments for learning including the use of computers, CDs, DVDs, communication channels and the internet. (Bardi \& Jailani, 2015; L Herayanti \& Habibi, 2017). The combination of several types of media in one learning application that integrates technology is called multimedia. The use of multimedia is expected to facilitate learning carried out in the classroom so that the process of delivering material can be done easily and supports creative thinking processes for students (Armansyah, Sulton, \& Sulthoni, 2019; Sina, Farlina, Sukandar, \& Kariadinata, 2019). Creative thinking is one of the 21st century skills that students need. Creative thinking is understood as a series of activities related to sensitivity to a problem, considering new ideas or ideas with an open mind, and being able to provide solutions to a problem (Marliani, 2015; Suparmi, 2019).

The problem that occurs today is the low level of creative thinking in students (Insyasiska, Zubaidah, \& Susilo, 2015; Moma, 2017). This is because learning is centered on the teacher (teacher center) so that students only receive material without thinking so that it affects low learning outcomes. This problem also occurs in one of the vocational schools. Based on the results of observations made at the Department of Computer Network Engineering at SMKN 2 Payakumbuh, it was found the problem of low student learning outcomes, especially in operating system subjects. The operating system is still below the average, which is less than a value of 70 . This shows that the practical value of students in operating system teaching materials is still low. The low value of the practice is caused by the lack of critical thinking skills in students. The low thinking ability of students is caused by the tendency of remembering and understanding aspects in the learning process (Khofiyah, Santoso, \& Akbar, 2019; Koriyah \& Harta, 2015). The practical value of students is still low, considering that the ability in practice or competence is the main part of students who come from school. So that vocational learning methods and strategies are needed that can improve the results of practical values.

The low practical value of the operating system requires alternative solutions to increase the practical value of students. One solution that can be applied is to use an innovative learning model in operating system teaching materials. The innovative learning model in question is also inseparable from constructivist understanding in learning (Nurhidayati, 2017; Waseso, 2018). Constructivistic understanding teaches students to find new things for themselves and develop their own understanding ideas so that innovative learning models are needed (Darwin, Ridwan, \& Ahyanuardi, 2020; Prayito, 2011). The low learning outcomes of operating systems require alternative solutions to improve student learning outcomes. One solution that can be applied is to use an innovative learning model on operating system material. The intended innovative learning model cannot be separated from improving student learning outcomes (Effendi \& Hendriyani, 2020; Sulfemi, 2019). As well as understanding the operating system material so that students do not experience difficulties in practicing. One of the innovative learning models that can be used is the use of a professional flip multimedia module based on 3D pageflip with a flipped classroom approach to improve students' creative thinking skills.

Flipped classroom is one of the new learning models and is still rarely used. The sequence of the learning process is reversed from conventional learning where students are given assignments at home as preparation for lectures. In the classroom, students will apply active learning guided by educators (Kurniawati, 2019; Utami, 2017). There are 4 pillars of the Flipped classroom learning model, namely Flexible Environment, Learning Culture, Intentional Content, and Professional Educator (Juniantari, Pujawan, \& Widhiasih, 2019; Sojayapan \& Khlaisang, 2018). The role of educators is to help students find topics and learning objectives in depth so that students' thinking skills can be honed. Based on Bloom's taxonomy theory, the stage of flipping the class in the process of remembering new material introduced by students outside the classroom as their homework. While the stages of implementation, analysis, evaluation, and creation are carried out by students and educators in the learning process in the classroom. Basically the concept of the flipped classroom learning model reverses learning habits in general. If learning is usually done in class, in the flipped classroom learning model the learning process is carried out at home. While the tasks that become homework, the learning process can be done flexibly because this learning model is carried out by students at home (Albiladi, 2019; Ningsih, Misdalina, \& Marhamah, 2017). Computer and network engineering vocational schools cannot be separated from operating system subjects. So this lesson requires a very serious learning and can not quickly understand it. One of the 
software that can be used to make flip books is 3D pageflip professional. Rozy \& Anggana (2017) stated that professional 3D pageflip is a flash flip book application that can be used to convert PDF, Word, PowerPoint, and Excel files into flip books, e-brochures, flip modules, and 3-dimensional e-books. magazine. The results of previous studies show that multimedia-based flip books can improve student learning outcomes (Hayati, Budi, \& Handoko, 2015).

Previous research conducted by Sinaga (2017) stated that Flipped classrooms in basic chemistry courses can improve students' self-regulated learning. Rahayu (2017) stated that the Flipped classroom learning strategy on the Pythagorean class VIII SMP material in terms of gender showed very good results. In addition, the application of the Turning class model is effective in improving the creative attitude, responsibility, and learning skills of class XI students of SMKN 1 Gedangsari (Damayanti \& Sutama, 2016). Therefore, the Flipped Classroom learning model is an alternative innovative learning model that is suitable to be applied to operating system teaching materials for computer network engineering students. This study aims to analyze the effectiveness of the Flip Book multimedia with the flipped classroom approach in vocational schools. The use of a professional multimedia flip book based on 3d pageflip with a flipped classroom approach is expected to increase students' competence when carrying out practice on operating systems subjects and ultimately affect the results of students' practice scores in these subjects.

\section{Method}

In this study, the research design used by the researcher was a quasi-experimental design, namely pretest posttest design with untreated pretest-posttest control group design (Sugiyono, 2016). The research design used two sample groups, namely the experimental group and the control group. The research design used is in the table below.

Table 1. Design Pretest-Posttest (Alatas et al., 2011)

\begin{tabular}{llll}
\hline Pre-tes & Treatment & Post-test & Subject \\
\hline Kel TKJ 1 & $\sqrt{ }$ & Kel TKJ 1 & (Experiment) \\
Kel TKJ 2 & & Kel TKJ 2 & (Control) \\
\hline
\end{tabular}

The research design used an experimental group, namely TKJ 1 class and one control group, namely TKJ 2 class, where both groups received the same treatment regarding the learning objectives and subject matter provided, but the learning methods were different. The experimental class used the Flip Multimedia book with the Flipped Classroom Approach, while the control group used printed books and hangouts provided by the teacher. The initial ability of students is known by using the pretest score. Data collection techniques using observation, interviews, and tests. The PDA pre-test was conducted to collect data about the students' initial abilities, while the post-test was conducted to test the effect of treatment. The parties involved in this research include: researchers who act as research designers and observers when the research is carried out, operating system subject teachers who act as field implementers, and TKJ class students as research subjects.

The data analysis of this research begins with the prerequisite test of data analysis, namely: Normality test. This step aims to determine whether the data obtained are normally distributed or not. If the data obtained is normally distributed, the next step that the researcher will take is a parametric statistical test, whereas if the processed data is not normally distributed, the researcher must use a non-parametric statistical test (Sugiyono, 2016). In this study the normality test was carried out using the Kolmogrov Smirnov test. Using SPSS v.21 Homogeneity test was conducted to test/compare whether the variation of the study population was not much different. In other words, the analyzed data comes from populations that have almost the same diversity. After testing the two classes, namely the normality test and the homogeneity test, the next step is to perform an independent test until $\mathrm{t}$. The $\mathrm{t}$-test is used for the data analysis process, the results of which are decisions / conclusions based on hypotheses. T-test in statistical data analysis using SPSS v. 21

\section{Result and Discussion}

The research was carried out at the Computer Network Engineering Department of SMKN 2 Payakumbuh semester 1 on the subject of operating systems. This study involved two classes, namely TKJ 1 class and TKJ 2 class with 43 students as research objects. The students are divided into 21 classes of TKJ 1 and 22 classes of TKJ 2. The two classes are detailed as follows; The TKJ 1 class is used as an experimental class with the help of Flip Multimedia books with a Reverse Class Approach, while the TKJ 2 class uses printed books and a hangout provided by the teacher. The two classes were made different because they tested their influence in using learning. The research was carried out in 6 meetings, where 3 meetings were for the experimental class 
and 3 times for the control class with a duration of 2 X 45 minutes for each class. During the research activities carried out in both classes, the researcher gave a pretest first to see the initial abilities of the two classes. While the posttest is given after the learning is complete. Furthermore, the mapping of learning outcomes that the researchers had done in two classes, namely the experimental class and the control class, was carried out as shown in table 2 .

Tabel 2. Hasil Pre-test Kelas Eksperimen dan Kelas Kontrol

\begin{tabular}{lcccccc}
\hline Kelas & N & Minimum & Maxsimum & Mean & Std. Deviation & Variance \\
\hline Eksperimen & 21 & 15 & 50 & 27.14 & 9.161 & 83.93 \\
Kontrol & 22 & 15 & 50 & 24.32 & 10.035 & 100.70 \\
Valid N & & & & & & \\
\hline
\end{tabular}

Based on the results obtained in Table 2, it can be analyzed and explained that the average value of the two classes used as research objects tends to be relatively the same, only 0.01 different. This shows that the experimental class and the control class have the same initial ability. The average pretest score of students in the experimental class is 27.14 with the highest score of 50 and the lowest being 15 , while the control class is 24.32 with the highest score of 50 and the lowest being 15 . So it can be concluded that the ability of each student in the experimental class and class controls have the same initial capabilities. Furthermore, the results of the posttest experimental class and control class are shown in Table 3.

Tabel 3. Hasil Post-test Kelas Eksperimen Dan Kelas Kontrol

\begin{tabular}{lcccccc}
\hline Kelas & N & Minimum & Maxsimum & Mean & Std. Deviation & Variance \\
\hline Eksperimen & 21 & 60 & 95 & 76.14 & 9.634 & 92.829 \\
Kontrol & 22 & 45 & 80 & 71.34 & 10.632 & 113.041 \\
Valid N & & & & & & \\
\hline
\end{tabular}

The scores of students in the experimental class and control class were different because of the use of learning using the Multimedia Flip book with the Flipped Classroom Approach for the experimental class and using printed books and hangouts provided by the teacher in the control class. show the difference. Where the experimental class has an average value of 76.14 with the highest score of 95 and the lowest score of 60 , while the control class has an average value of 71.34 with the highest score of 80 and the lowest value of 45 . On the other hand, the standard deviation of the two classes is the experimental class 9,634 while the control class is 10,632. In analysis, the data that has been obtained in the experimental class and control class shows a significant difference. Which is for the experimental class average value on the initial ability (pretest) of 27.14 with the highest score of 50 and the lowest of 15 while the posttest is 76.14 with the highest score of 95 and the lowest is 60 . As for the control class the average score for ability The initial (pretest) was 24.32 with the highest score of 50 and the lowest was 15 , while the posttest was 71.134 with the highest score of 80 and the lowest was 45. The difference shows the difference in the effectiveness of using learning models in the two different classes, which results in different results. If the researcher compares the two classes, of course, it can be clearly seen that there are differences in student learning outcomes in the experimental class and the control class. This shows that the experimental class is better than the control class. Furthermore, the two classes are normally distributed so there is no need to use SPSS v.21 with Kolmogrov Smirnov. The distribution of the two classes is said to be normal after testing to find out how normality is by using the Post-Test Result Normality test for the Experimental Class and the One Sample Kolmogorov-Smirnov Test Control Class. The test was carried out by looking at the final ability of the two classes after being given learning treatment. For more details see table 4.

Tabel 4. Uji Normalitas Hasil Post-test Kelas Eksperimen dan Kelas Kontrol One- Sample KolmogorovSmirnov Test

\begin{tabular}{llll}
\hline & & Eksperimen & Kontrol \\
\hline $\mathbf{N}$ & & $\mathbf{2 1}$ & $\mathbf{2 2}$ \\
\hline Normal Parameters & Mean & 76,14286 & 65.2273 \\
& Std. Deviation & 9,634759 & 10.63208 \\
Most Extreme Differences & Absolute & 0,11864 & .219 \\
& Positive & 0,11864 & .108 \\
& Negative & $-0,08412$ & -.219 \\
Kolmogorov-Smirnov Z & & $\mathbf{0 , 5 4 3 6 7 5}$ & $\mathbf{1 . 0 2 6}$
\end{tabular}


The data obtained in table 4 can be analyzed and explained that the posttest value data for the experimental class is 0.11 and the control class is 0.21 which means the experimental class or control class > 0.05 , then Ho is accepted so that it is accepted. shows the post-test results. the experimental class and the control class were normally distributed. The homogeneity test was then carried out to see the data variance of the two classes as shown in table 5.

Tabel 5. Uji Homogenitas Hasil Post-test Kelas Eksperimen dan Kelas Kontrol

\begin{tabular}{cccc}
\hline & \multicolumn{2}{c}{ Postest } & \\
\hline Levene Statistic & df1 & df2 & Sig. \\
\hline .054 & 1 & 41 & .818 \\
\hline
\end{tabular}

The data obtained in table 5 can be analyzed and explained that there is a significant posttest value of 0.818 which means $>0.05$. This shows that the experimental class and the control class have the same variance. So it can be concluded that the experimental class using the Flip Multimedia book with the Inverted Class Approach and the control class using the printed book have the same or homogeneous variants. After testing the two classes, namely the normality test and homogeneity test, then an independent sample $t$ test was carried out with the help of the SPSS version 21 program as shown in table 6.

Tabel 6. Uji Hipotesis Hasil Post-test Kelas Eksperimen dan Kelas Kontrol Independent Samples Test

\begin{tabular}{|c|c|c|c|c|c|c|c|c|}
\hline \multirow{2}{*}{\multicolumn{2}{|c|}{ Levene's Test for Equality of }} & \multicolumn{3}{|c|}{ Variances } & \multicolumn{4}{|c|}{ t-test for Equality ofMeans } \\
\hline & & $\mathrm{F}$ & Sig & $\mathrm{t}$ & df & $\begin{array}{c}\text { Sig. (2- } \\
\text { tailed } \\
\text { ) }\end{array}$ & $\begin{array}{c}\text { Mean } \\
\text { Differen ce }\end{array}$ & $\begin{array}{c}\text { Std. Error } \\
\text { Differen } \\
\text { ce }\end{array}$ \\
\hline $\begin{array}{c}\text { Poste } \\
\text { st }\end{array}$ & $\begin{array}{c}\text { Equal variances } \\
\text { assumed }\end{array}$ & $\begin{array}{c}.05 \\
4 \\
\end{array}$ & $\begin{array}{c}.81 \\
8 \\
\end{array}$ & $\begin{array}{c}3.50 \\
1\end{array}$ & 41 & .001 & -10.864 & 3.103 \\
\hline & $\begin{array}{l}\text { Equal variances not } \\
\text { assume } \quad \mathrm{d}\end{array}$ & & & $\begin{array}{c}3.49 \\
0 \\
\end{array}$ & $\begin{array}{c}39.72 \\
6\end{array}$ & .001 & -10.864 & 3.113 \\
\hline
\end{tabular}

Based on table 6 it can be analyzed and explained that the data on the $t$ count is 3.501 while the $t$ table obtained by the researcher is 0.05 which is divided by 2 the result is 0.025 . Furthermore, for degrees of freedom, the result is (df) $n-2=41$ or $41-2=39$, which means the value becomes 43 (df 43 ) from 1,997. So it can be concluded that the value of $t$ count $<t$ table $(3.501<1.997)$. This means that Ho is rejected so that Ha is accepted or it can be said that learning to use the Flipped Multimedia book with the Flipped Classroom Approach is more effective than learning to use printed books for class XI students of TKJ SMK 2 Negeri Payakumbuh on the subject of Operating Systems.

The data collection showed significance in the experimental class where there was an increase in initial ability and after being given treatment learning through the Multimedia Flip book with the Flipped Classroom Approach and it can be analyzed that learning with the Flipped Multimedia Book Classroom Approach. Multimedia flip book consists of a combination of text, animation, video, sound and so on so that it can provide audio and visual stimuli that will improve memory and can make it easier for students to understand the material. (Manurung \& Panggabean, 2020; Mulyadi, Wahyuni, \& Handayani, 2016). There is a match between the theory and the facts on the ground that learning the Multimedia Flip book with the Flipped Classroom Approach makes students more enthusiastic about learning because there is an increase after being given treatment. In addition, data collection in the control class only showed a slight increase in initial abilities and after being given treatment using printed books and hangouts provided by the teacher. After carrying out the results of the influence of learning using the Multimedia Flip book with the Flipped Classroom approach, the researchers provide and display the results of observations during the learning process. The results showed that the experimental class that used learning using the Multimedia Flip book with the Flipped Classroom approach could make students more active and active in learning because the learning was interesting because of the supportive design so that students were active. The Flipped Classroom approach is able to increase student activity in learning (Arrosagaray, González-Peiteado, Pino-Juste, \& Rodríguez-López, 2019; Lukitasari, Purnamasari, Utami, \& Sukri, 2019). In addition, learning using Flip Multimedia books with the Flipped Classroom approach makes students more independent in studying the material and doing the tasks displayed. So don't be surprised if the final results obtained are much better than before being treated.

Learning learning using Multimedia Flip book with Flipped Classroom approach creates interaction between students and teachers. The final score of these students varies according to their respective abilities 
because students do not have to cheat and look for answers through internet applications so that it is purely from the abilities of each student without being covered up. Problem work is also carried out with the duration of time that has been made by the teacher so that students must try as much as possible to make time efficient so as not to miss and have limitations in answering. The results obtained later certainly make comparisons with others. In essence, the ability of students in the experimental class using the Multimedia Flip book with the Flipped Classroom approach is much higher than the control class using printed books. (Albiladi, 2019; Hayati et al., 2015). Based on the results of previous research shows that multimedia can improve student learning outcomes (Prasetya, Ade Yama Wahyu Nur \& Akbar, 2018; Sina et al., 2019).

Learning with a flipped classroom approach, the process of delivering material such as face-to-face or traditional methods is transferred from classroom learning and replaced with active learning and collaborative assignments (Soni et al., 2018; Wulandari et al., 2020). In the reversed classroom, more time is devoted to practical activities and not used to study theoretical material (Alfi, Sumarmi, \& Amirudin, 2016; Hermawanto, Kusairi, \& Wartono, 2013). Learning materials in flipped classroom were first given by educators to be studied by students outside the classroom independently, while learning was carried out for interactive activities between students and educators that emphasized the development of high-level abilities of students. Flipped classroom is applied with the condition that the provision of teaching materials is given to students before students receive learning in class. Sophisticated online infrastructure and application technology make reverse classroom implementations using media develop faster (Kurtz, Tsimerman, \& Steiner, 2014; Siregar \& Manurung, 2020). In flipped classroom learning, the most important thing is not only material or video as media and others, but how the learning design supports flipped classroom learning as a whole. Thus, educators have a major role in integrating the content that students have learned outside the classroom with the learning that will be carried out in the classroom as a whole.

Thus, although not all learning that uses the Multimedia Flip book with the Flipped Classroom approach has advantages under current conditions, the influence of other obstacles can at least reduce the quality of adequate supporting facilities. Basically, students may like learning to use Flip Multimedia books with the Flipped Classroom approach because it makes it easier for them to connect and work with their classmates and teachers online, and it may not cause students any difficulties. In addition, teachers may want to use Flip Multimedia books with Flipped Classroom approach because of its simple function for teachers to create and manage their classroom communities, finally, using Flip Multimedia books with Flipped Classroom approach offers privacy for both. teachers and students

\section{Conclusion}

Learning using Multimedia Flip book with Flipped Classroom approach is more innovative and interactive so that students are active and active in learning. In the learning process, students are more interested in studying the Multimedia Flip book with the Flipped Classroom approach which encourages the learning outcomes obtained. It can be concluded that the Flipped Multimedia book with the Flipped Classroom approach can improve student learning outcomes.

\section{References}

Albiladi, K. (2019). Blended Learning in English Teaching and Learning: A Review of the Current Literature. Journal of Language Teaching and Research, 10(2), 232-238. https://doi.org/http://dx.doi.org/10.17507/jltr.1002.03.

Alfi, C., Sumarmi, S., \& Amirudin, A. (2016). Pengaruh Pembelajaran Geografi Berbasis Masalah Dengan Blended Learning Terhadap Kemampuan Berpikir Kritis Siswa SMA. Jurnal Pendidikan Teori, Penelitian, Dan Pengembangan, 4(1). https://doi.org/http://dx.doi.org/10.17977/jp.v1i4.6203.

Armansyah, F., Sulton, S., \& Sulthoni, S. (2019). Multimedia Interaktif Sebagai Media Visualisasi Dasar-Dasar Animasi. Jurnal Kajian Teknologi Pendidikan, 2(3), 224. https://doi.org/10.17977/um038v2i32019p224.

Arrosagaray, M., González-Peiteado, M., Pino-Juste, M., \& Rodríguez-López, B. (2019). A comparative study of Spanish adult students' attitudes to ICT in classroom, blended and distance language learning modes. Computers and Education, 134(October 2018), 31-40. https://doi.org/10.1016/j.compedu.2019.01.016.

Bardi, \& Jailani. (2015). Pengembangan Multimedia Berbasis Komputer Untuk Pembelajaran Matematika Bagi Siswa SMA Pendidikan. Jurnal Inovasi Teknologi, 2(1), 49-63. https://doi.org/https://doi.org/10.21831/tp.v2i1.5203.

Damayanti, \& Sutama. (2016). Efektivitas Flipped Classroom Terhadap Sikap Dan Ketrampilan Belajar Matematika Di SMK. Jurnal Managemen Pendidikan, 11(2).

Darwin, Ridwan, \& Ahyanuardi. (2020). Efektivitas Pengembangan Modul Berbasis Konstruktivisme Pada Mata Pelajaran Sistem Komputer Bagi Siswa TKJ Tingkat SMK. Jurnal EDUTECH Universitas Pendidikan 
Ganesha, 8(1), 147-155. https://doi.org/http://dx.doi.org/10.23887/jeu.v8i1.27259.

Effendi, H., \& Hendriyani, Y. (2020). The Conceptual and Hypothetical Model of Interactive Blended Problem Based Learning. JPI (Jurnal Pendidikan Indonesia), 8(2), 285. https://doi.org/10.23887/jpiundiksha.v8i2.24162.

Hayati, S., Budi, A. S., \& Handoko, E. (2015). Pengembangan Media Pembelajaran Flipbook Fisika untuk Meningkatkan Hasil Belajar Peserta Didik. Prosiding Seminar Nasional Fisika (E-Jurnal), 4(1). Retrieved from http://journal.unj.ac.id/unj/index.php/prosidingsnf/article/view/4810/3587.

Herayanti, L, \& Habibi, H. (2017). Model Pembelajaran Berbasis Masalah Berbantuan Simulasi Komputer untuk Meningkatkan Keterampilan Berpikir Kritis Calon Guru Fisika. Jurnal Pendidikan Fisika Dan Teknologi, 1(1), 61-66. https://doi.org/10.29303/jpft.v1i1.236.

Herayanti, Lovy, Habibi, H., \& Fuaddunazmi, M. (2017). Pengembangan Media Pembelajaran Berbasis Moodle pada Matakuliah Fisika Dasar. Jurnal Cakrawala Pendidikan, 36(2), 210-219. https://doi.org/10.21831/cp.v36i2.13077.

Hermawanto, Kusairi, \& Wartono. (2013). Pengaruh Blended Learning terhadap Penguasaan Konsep dan Penalaran Fisika Peserta Didik Kelas X. Jurnal Pendidikan Fisika Indonesia, 9(57), 67-76. https://doi.org/https://doi.org/10.15294/jpfi.v9i1.2582.

Insyasiska, Zubaidah, \& Susilo. (2015). Pengaruh Project Based Learning terhadap Motivasi Belajar, Kreativitas, Kemampuan Berpikir Kritis, dan Kemampuan Kognitif Siswa pada Pembelajaran Biologi. Jurnal Pendidikan Biologi, 7(1), 9-21. https://doi.org/http://dx.doi.org/10.17977/um052v7i1p9-21.

Juniantari, M., Pujawan, I. G. N., \& Widhiasih, I. D. A. G. (2019). Pengaruh Pendekatan Flipped Classroom Terhadap Pemahaman Konsep Matematika Siswa SMA. Journal of Education Technology. https://doi.org/10.23887/jet.v2i4.17855.

Khofiyah, H. N., Santoso, A., \& Akbar, S. (2019). Pengaruh Model Discovery Learning Berbantuan Media Benda Nyata terhadap Kemampuan Berpikir Kritis dan Pemahaman Konsep IPA. Jurnal Pendidikan: Teori, Penelitian, Dan Pengembangan, 61-67. https://doi.org/http://dx.doi.org/10.17977/jptpp.v4i1.11857.

Koriyah, V. N., \& Harta, I. (2015). Pengaruh Open-Ended terhadap Prestasi Belajar, Berpikir Kritis dan Kepercayaan Diri Siswa SMP. Pythagoras: Jurnal Pendidikan Matematika, 10(1), 95-105. https://doi.org/10.21831/pg.v10i1.9113.

Kurniawati, D. (2019). Penerapan Blended Learning Menggunakan Model Flipped Classroom Berbantuan Google Classroom Dalam Pembelajaran Matematika SMP. Jurnal Pendidikan Matematika, 7(1), 8-19.

Kurtz, G., Tsimerman, A., \& Steiner, O. (2014). The Flipped Classroom Answer to Future Learning? European Journal of Open, Distance and E-Learning, 17(2). https://doi.org/https://doi.org/10.2478/eurodl-20140027.

Lukitasari, Purnamasari, Utami, \& Sukri. (2019). Blended-Problem-Based Learning: How its impact on students' critical thingking skills? Jurnal Pendidikan Biologi Indonesia, 5(3), $425-434$. https://doi.org/https://doi.org/10.22219/jpbi.v5i3.10048.

Manurung, \& Panggabean. (2020). Improving Students' Thinking Ability In Physics Using Interactive Multimedia Based Problem Solving. Cakrawala Pendidikan, 39(2), 460-470. https://doi.org/https://doi.org/10.21831/cp.v39i2.28205.

Marliani. (2015). Peningkatan Kemampuan Berpikir Kreatif Matematis Siswa melalui Model Pembelajaran Missouri Mathematics Project (MMP). Jurnal Ilmiah Pendidikan MIPA, 5(1), 14-25. https://doi.org/https://doi.org/10.30998/formatif.v5i1.166.

Moma. (2017). Pengembangan Kemampuan Berpikir Kreatif dan Pemecahan Masalah Matematis Mahasiswa Melalui Metode Diskusi. Cakrawala Pendidikan, 36(1), 130-139. Retrieved from https://journal.uny.ac.id/index.php/cp/article/view/10402/pdf.

Mulyadi, D. U., Wahyuni, S., \& Handayani, R. D. (2016). Pengembangan Media Flash Flipbook Untuk Meningkatkan Keterampilan Berfikir Kreatif Siswa Dalam Pembelajaran IPA Di SMP. Jurnal Pembelajaran Fisika, 4(4). Retrieved from https://jurnal.unej.ac.id/index.php/JPF/article/view/2728.

Ningsih, Misdalina, \& Marhamah. (2017). Peningkatan Hasil Belajar dan Kemandirian Belajar Metode Statistika Melalui Pembelajaran Blended Learning. Al-Jabar: Jurnal Pendidikan Matematika, 8(2), 155-164. https://doi.org/https://doi.org/10.24042/ajpm.v8i2.1633.

Nurhidayati, E. (2017). Pedagogi Konstruktivisme dalam Praksis Pendidikan Indonesia. Indonesian Journal Of Educational Counseling, 1(1), 1-14. https://doi.org/https://doi.org/10.30653/001.201711.2.

Prasetya, Ade Yama Wahyu Nur, D. K., \& Akbar, S. (2018). Multimedia Interaktif pada Pembelajaran Tematik untuk Kelas IV Sekolah Dasar. Jurnal Pendidikan: Teori, Penelitian, Dan Pengembangan, 3(11), 14231427. https://doi.org/http://dx.doi.org/10.17977/jptpp.v3i11.11751.

Prayito. (2011). Pengembangan Perangkat Pembelajaran Matematika Humanistik Berbasis Konstruktivisme Berbantuan E-Learning Materi Segitiga Kelas VII. AKSIOMA Journal of Mathematics Education, 2(2). 
https://doi.org/https://doi.org/10.26877/aks.v2i2/Septembe.37.

Puspitorini, Subali, \& Jumadi. (2014). Penggunaan Media Komik Dalam Pembelajaran IPA Untuk Meningkatkan Motivasi Dan Hasil Belajar Kognitif Dan Afektif. Cakrawala Pendidikan, 33(3), 413420. Retrieved from https://journal.uny.ac.id/index.php/cp/article/view/2385/pdf.

Qumillaila, Susanti, \& Zulfiani. (2017). Pengembangan Augmented Reality Versi Android Sebagai Media Pembelajaran Sistem Ekskresi Manusia. Cakrawala Pendidikan, 34(1), 57-69. Retrieved from https://journal.uny.ac.id/index.php/cp/article/view/9786/pdf. \%0A.

Rahayu, L. P. (2017). Efektivitas Strategi Pembelajaran Flipped Classroom pada Materi Pythagoras SMP Kelas VIII Ditinjau Berdasarkan Gender. Prosiding Seminar Nasional Integrasi Matematika Dan Nilai-Nilai Islami, l(1). Retrieved from http://conferences.uin-malang.ac.id/index.php/SIMANIS/article/view/57.

Rozy, A. F., \& Anggana, Y. (2017). Pengembangan Media Pembelajaran Elektronika Berbasis 3D PageFlip pada Mata Pelajaran Penerapan Rangkaian Elektronika di SMK Negeri 1 Kediri. Jurnal Pendidikan Teknik Elektro Universitas Negeri Surabaya, 6(1). Retrieved from https://jurnalmahasiswa.unesa.ac.id/index.php/jurnal-pendidikan-teknik-elektro/article/view/17347.

Sina, I., Farlina, E., Sukandar, S., \& Kariadinata, R. (2019). Pengaruh Multimedia Interaktif dalam Pembelajaran Matematika Terhadap Kemampuan Komunikasi Matematis Siswa. Suska Journal of Mathematics Education, 5(1), 57. https://doi.org/10.24014/sjme.v5i1.5081.

Sinaga. (2017). Penerapan Flipped Classroom Pada Mata Kuliah Kimia Dasar Untuk Meningkatkan SelfRegulated Learning Belajar Mahasiswa. Jurnal Inovasi Pendidikan Kimia, 11(2). Retrieved from https://journal.unnes.ac.id/nju/index.php/JIPK/article/view/10609..

Siregar, \& Manurung. (2020). Pengaruh Blended Learning terhadap Kreativitas Mahasiswa Calon Guru di Universitas Negeri Medan. Edumatika: Jurnal Riset Pendidikan Matematika, 3(1). https://doi.org/https://doi.org/10.32939/ejrpm.v3i1.485

Sojayapan, \& Khlaisang. (2018). The effect of a flipped classroom with online group investigation on students' team learning ability. Kasetsart Journal of Social Sciences, 30(1). Retrieved from https://so04.tcithaijo.org/index.php/kjss/article/view/229130.

Soni, Hafid, Hayami, Fatma, Wenando, Amien, ... Mukhtar. (2018). Optimalisasi Penggunaan Google Classroom, E-Learning \& Blended Learning sebagai Media Pembelajaran Bagi Guru dan Siswa di SMK Negeri 1 Bangkinang. Jurnal Pengabdian Untukmu Negeri, 21. https://doi.org/https://doi.org/10.37859/jpumri.v2i1.361.

Sulfemi, W. B. (2019). Model Pembelajaran Kooperatif Mind Mapping Berbantu Audio Visual Dalam Meningkatkan Minat, Motivasi Dan Hasil Belajar Ips. Jurnal PIPSI (Jurnal Pendidikan IPS Indonesia), 4(1), 13. https://doi.org/10.26737/jpipsi.v4i1.1204.

Sunismi. (2015). Developing Guided Discovery Learning Materials Using Mathematics Mobile Learning Application As An Alternative Media For The Students Calculus II. Cakrawala Pendidikan, 34(3), 334-346. https://doi.org/https://doi.org/10.21831/cp.v3i3.7340.

Suparmi, N. W. (2019). Hasil Belajar Pemahaman Konsep Dan Berpikir Kreatif Siswa Dalam Pembelajaran Inkuiri Bebas Dan Inkuiri Terbimbing. Journal of Education Technology, 2(4), 192. https://doi.org/10.23887/jet.v2i4.16548.

Utami, I. S. (2017). Pengujian Validitas Model Blended Learning di Sekolah Menengah Kejuruan. Jurnal Ilmiah Pendidikan Teknik Elektro, 2(1), 1-10. https://doi.org/http://dx.doi.org/10.30870/volt.v2i1.963.

Waseso, H. P. (2018). Kurikulum 2013 Dalam Prespektif Teori Pembelajaran Konstruktivisme. Ta'lim, 1(1), 5972. https://doi.org/https://doi.org/10.29062/ta'lim.v1i1.632.

Wulandari, Sudatha, \& Simamora. (2020). Pengembangan Pembelajaran Blended Pada Mata Kuliah Ahara Yoga Semester II di IHDN Denpasar. Jurnal Edutech Undiksha, 8(1), 1-15. https://doi.org/http://dx.doi.org/10.23887/jeu.v8i1.26459.

Yusri. (2016). Pengaruh Penggunaan Media Teknologi Informasi dan Komunikasi (TIK) dengan Prestasi Belajar Bahasa Inggris Peserta Didik Kelas X di SMAN I Dekai Kabupaten Yahukimo. Ilkom Jurnal Ilmiah, 8(1), 49-56. https://doi.org/https://doi.org/10.33096/ilkom.v8i1.22.49-56. 